\title{
Radionuclides Transfer from Soil to Tea Leaves and Estimation of Committed Effective Dose to the Bangladesh Populace
}

\author{
Nurul Absar ${ }^{1}$, Jainal Abedin ${ }^{1}$, Md. Mashiur Rahman ${ }^{2}$, Moazzem Hossain Miah ${ }^{3}$, Naziba Siddique ${ }^{3}$, \\ Masud Kamal ${ }^{4}$, Mantazul Islam Chowdhury ${ }^{4}$, Abdelmoneim Adam Mohamed Sulieman ${ }^{5}$ (D), \\ Mohammad Rashed Iqbal Faruque ${ }^{6}\left(\mathbb{D}\right.$, Mayeen Uddin Khandaker ${ }^{7, *}(\mathbb{D}$, David Andrew Bradley 7,8 \\ and Abdullah Alsubaie ${ }^{9}$
}

check for

updates

Citation: Absar, N.; Abedin, J.; Rahman, MM.; Miah, M.M.H.; Siddique, N.; Kamal, M.; Chowdhury, M.I.; Sulieman, A.A.M.; Faruque, M.R.I.; Khandaker, M.U.; et al. Radionuclides Transfer from Soil to Tea Leaves and Estimation of Committed Effective Dose to the Bangladesh Populace. Life 2021, 11, 282. https://doi.org/10.3390/ life11040282

Academic Editors:

Fabrizio Ambrosino and Supitcha Chanyotha

Received: 2 March 2021

Accepted: 24 March 2021

Published: 27 March 2021

Publisher's Note: MDPI stays neutral with regard to jurisdictional claims in published maps and institutional affiliations.

Copyright: (c) 2021 by the authors. Licensee MDPI, Basel, Switzerland. This article is an open access article distributed under the terms and conditions of the Creative Commons Attribution (CC BY) license (https:/ / creativecommons.org/licenses/by/ $4.0 /)$.
1 Department of Computer Science and Engineering, BGC Trust University Bangladesh, Chittagong 4381, Bangladesh; nabsar@bgctub.ac.bd (N.A.); abedinj7110@bgctub.ac.bd (J.A.)

2 Hughes Network Systems, 11717 Exploration Lane, Germantown, MD 20876, USA; mashiur.rahman@hughes.com

3 Department of Physics, University of Chittagong, Chittagong 4331, Bangladesh; mhmiah@cu.ac.bd (M.H.M.); snaziba@yahoo.com (N.S.)

4 Atomic Energy Centre-Chittagong, Radioactivity Testing and Monitoring Laboratory, Bangladesh Atomic Energy Commission, Chittagong 4209, Bangladesh; masud.kamal@gmail.com (M.K.); mantaz54@yahoo.com (M.I.C.)

5 Department of Radiology and Medical Imaging, College of Applied Medical Sciences, Prince Sattam Bin Abdulaziz University, P.O. Box 422, Alkharj 11942, Saudi Arabia; a.sulieman@psau.edu.sa

6 Space Science Centre (ANGKASA), Universiti Kebangsaan Malaysia, Bangi 43600, Malaysia; rashed@ukm.edu.my

7 Centre for Applied Physics and Radiation Technologies, School of Engineering and Technology, Sunway University, Bandar Sunway 47500, Malaysia; d.a.bradley@surrey.ac.uk

8 Centre for Nuclear and Radiation Physics, Department of Physics, University of Surrey, Guildford, Surrey GU2 7XH, UK

9 Department of Physics, College of Khurma, Taif University, P.O. Box 11099, Taif 21944, Saudi Arabia; a.alsubaie@tu.edu.sa

* Correspondence: mayeenk@sunway.edu.my

Abstract: Considering the probable health risks due to radioactivity input via drinking tea, the concentrations of ${ }^{226} \mathrm{Ra},{ }^{232} \mathrm{Th},{ }^{40} \mathrm{~K}$ and ${ }^{137} \mathrm{C}$ s radionuclides in the soil and the corresponding tea leaves of a large tea plantation were measured using high purity germanium (HPGe) $\gamma$-ray spectrometry. Different layers of soil and fresh tea leaf samples were collected from the Udalia Tea Estate (UTE) in the Fatickchari area of Chittagong, Bangladesh. The mean concentrations (in Bq/ $\mathrm{kg}$ ) of radionuclides in the studied soil samples were found to be $34 \pm 9$ to $45 \pm 3$ for ${ }^{226} \mathrm{Ra}, 50 \pm 13$ to $63 \pm 5$ for ${ }^{232} \mathrm{Th}, 245 \pm 30$ to $635 \pm 35$ for ${ }^{40} \mathrm{~K}$ and $3 \pm 1$ to $10 \pm 1$ for ${ }^{137} \mathrm{Cs}$, while the respective values in the corresponding tea leaf samples were $3.6 \pm 0.7$ to $5.7 \pm 1.0,2.4 \pm 0.5$ to $5.8 \pm 0.9,132 \pm 25$ to $258 \pm 29$ and $<0.4$. The mean transfer factors for ${ }^{226} \mathrm{Ra},{ }^{232} \mathrm{Th}$ and ${ }^{40} \mathrm{~K}$ from soil to tea leaves were calculated to be $0.12,0.08$ and 0.46 , respectively, the complete range being $1.1 \times 10^{-2}$ to 1.0 , in accordance with IAEA values. Additionally, the most popularly consumed tea brands available in the Bangladeshi market were also analyzed and, with the exception of ${ }^{40} \mathrm{~K}$, were found to have similar concentrations to the fresh tea leaves collected from the UTE. The committed effective dose via the consumption of tea was estimated to be low in comparison with the United Nations Scientific Committee on the Effects of Atomic Radiation (UNSCEAR) reference ingestion dose limit of $290 \mu \mathrm{Sv} / \mathrm{y}$. Current indicative tea consumption of $4 \mathrm{~g}$ /day/person shows an insignificant radiological risk to public health, while cumulative dietary exposures may not be entirely negligible, because the UNSCEAR reference dose limit is derived from total dietary exposures. This study suggests a periodic monitoring of radiation levels in tea leaves in seeking to ensure the safety of human health.

Keywords: soil; tea leaves; HPGe $\gamma$-ray spectrometry; terrestrial and anthropogenic radionuclides; threshold consumption rate; committed effective dose 


\section{Introduction}

The most common forms of ionizing radiation on earth, resulting from terrestrial, extraterrestrial and anthropogenic sources, are $\alpha$ - and $\beta$-particles and $\gamma$-rays [1,2]. According to the National Council on Radiation Protection and Measurements (NCRP), environmental radiation is the most significant source of radiation exposure to humans [3]. Interestingly, although the International Atomic Energy Agency (IAEA) reported that the public exposure from natural radiation is of little health concern [4], the World Nuclear Association (WNA) states that any dose of radiation involves a possible risk to human health [5]. Since ${ }^{238} \mathrm{U}$ and ${ }^{232} \mathrm{Th}$ decay series and singly occurring ${ }^{40} \mathrm{~K}$ are the most abundant radionuclides found naturally in soil, air, water, rocks, plants and foodstuffs [5], to protect the public against unwanted exposures to natural radiation, the radioactivity in environmental samples, including foodstuffs, needs to be monitored periodically [4].

The surface soil, especially the top layer in the earth, is a mixture of various components in the natural environment [6,7]. Although the main source of $U$, Th and $K$ is the earth crust, their contents appear at varying levels in the soils of different regions in the world following the variation of the local geology [8]. In addition to the prevailing concentration of terrestrial radionuclides in acidic soils, at high altitudes the contribution from extraterrestrial radioactivity may be enhanced, moreover with fallout of artificial radionuclides that may be subject to greater deposition. The latter concerns atmospheric nuclear device testing or unplanned phenomena such as the Three Mile Island power plant accident, the Chernobyl accident and the Fukushima Dai-ichi nuclear power plant accident [9-12]. Regardless of origin (i.e., natural or artificial), the radionuclides may appear in plants along with the uptake of minerals and nutrients required for their vitality, majorly by the root system [13]. Their availability in plant life enables them to be transported to humans via the daily intake of foodstuffs [14-16]. Thus, it is necessary to know the natural radioactivity in a particular area to obtain their distribution, modelling and transport processes leading to the estimation of radiation dose and hazards to the general population [6].

Due to its pleasant taste, aroma and positive physiological functions, tea is one of the most popular stimulating drinks in the world after water [17-19]. It is generally obtained by processing the leaves and leaf buds of the Camellia sinensis plant. Primarily there are four types of processed teas: green, black, oolong and brick tea [20]. Green tea is obtained by drying and roasting the tea leaves without any fermentation, whereas an additional fermentation produces black tea leaves. A partial fermentation of tea leaves results in oolong tea. Brick tea is made from the blocks of whole or finely ground black tea, compressed in a form under extremely high pressure. Asian populations generally drink the semi-fermented green tea and fermented black teas [21] as a hot drink. While, at present, tea is cultivated in more than 40 countries in the world, the major portion (90\%) is produced by Asian countries [22]. Due to the presence of biologically active compounds (antitoxin, antioxidant, anti-inflammatory, antibacterial, antiviral, anti-carcinogenic, etc.) like polyphenols, amino acids and vitamins in tea [23,24], tea drinking has been promoted for centuries [25-27]. Controversies about the benefits and risks due to the consumption of tea are not completely absent, but the few reported toxic effects are outclassed by its countless health-promoting benefits [28]. Harmful effects like stomach ache, intestinal gas, heartburn and abdominal pain from over consumption of tea are identified due to the presence of caffeine, aluminum and the influence of tea polyphenols on iron bioavailability [29].

Following the suitable geographical location and weather conditions for tea plantation, tea plantations were established in the hilly areas of Sylhet, Moulavibazar, Comilla and Chittagong regions in Bangladesh, centuries ago [30]. Moreover, due to recent developments in socio-economic conditions, tea consumption is increasing at a significant level among Bangladeshi population [31]. In producing more than 95 million $\mathrm{kg}$ of tea in 2019, harvested from about 115,757 hectares of land, Bangladesh has become the world's tenth largest tea producer and the world's ninth tea exporting country [32]. As a member of Bangladesh Tea Board and Bangladesh Tea Association, the Udalia Tea Estate (UTE), since 1962, has played a very important role in quality tea production. In recent times, the UTE 
has come to be ranked highly among the existing tea estates in Bangladesh. In meeting the growing domestic demand for premium black and green tea as well as that of international markets, UTE has secured a position not only as a tea producer but also as a multi-product estate. In particular, it enjoys abundant rainfall, is in an area of elevated altitude above sea level and has acidic and well-draining soils, all combining to make favorable conditions for tea production.

Since plants produce their necessary energy via the use of leaves together with the photosynthesis process, the leaves may have more activity than the other parts of plants, therefore they may contain relatively more radionuclides which are normally taken up by the root system along with other minerals. Moreover, leaves are more exposed to aerial deposition, e.g., radionuclides in dust or radionuclide particles themselves, if there are any artificial phenomena in the surrounding environment or nearby countries. Therefore, tea plants may be subjected to direct and indirect contamination of various radionuclides, and these radionuclides can be distributed in different parts of the plants according to the chemical characteristics and parameters of the plants and soil [33]. Since tea forms the second most popular drink (after water) in all populations in Bangladesh, the presence of a low level of radioactive material in tea leaves may produce a non-negligible health hazard via cumulative exposures. By acknowledging that ingestion doses above permissible levels are harmful for human beings [34], assessment of radionuclides due to the consumption of foodstuffs is important for public health. Furthermore, assessment of any release of radioactivity to the environment is important for the protection of public health, especially if the released radioactivity can enter into the food chain [35].

While studies of natural radioactivity in various foodstuffs are available in the literature, information on the distribution and enrichment of radionuclides in tea leaves is sparse, especially in tea leaves collected from the major tea gardens including the UTE in Bangladesh. The main objectives of the present study are to determine the transfer of radionuclides from soil to tea leaves harvested from the Udalia Tea Estate, further calculating the associated health hazards following the consumption of tea by the populace in Bangladesh. The activity concentrations of marketed tea leaves were also analyzed to observe the effect of manufacturing processes. This study may also help to enrich the radioactivity database on tea, i.e., the most popular stimulating drink.

\section{Experimental}

\subsection{Local Geology of the Udalia Tea Estate}

The Udalia Tea Estate (UTE) is located in the hilly region of Fatickchari Upazilla in the Chittagong district of Bangladesh (see in Figure 1). The UTE can be addressed as latitude $22^{\circ} 36^{\prime} 39^{\prime \prime}-22^{\circ} 39^{\prime} 41^{\prime \prime} \mathrm{N}$ and longitude $91^{\circ} 45^{\prime} 6^{\prime \prime}-91^{\circ} 51^{\prime} 15^{\prime \prime} \mathrm{E}$. The estate is covered by low hill ranges and terraces having an altitude of 30-46 m above sea level and contains an area of 3096 acres $(3.9 \mathrm{~km} \times 3.2 \mathrm{~km}=12.5$ square kilometer) [36]. The climate of this area is tropical monsoon. An average annual rainfall of about $2794 \mathrm{~mm}$ is recorded in this area, while July is the wettest month. The soils in this area are mainly yellowish to reddish brown, the texture is mostly clay loam on flat land while the hilly soil is mostly sandy loam to coarse sand, which is characterized by broken shale or sandstone and mottled sand at different depths [37]. The soils are strongly acidic and poor in organic matter and nutrients.

\subsection{Sample Collection and Preparation}

The samples (soil and tea leaves) were collected from different places in the Udalia Tea Estate (UTE). The sampling location was chosen on a random basis, but the distance between each sampling location was almost 700-800 m. Since the estate consists of ranges of low lying hills, separate hills were chosen as different sampling locations. A total of 5 locations were chosen for collecting the tea leaves and the surrounding soil samples throughout the garden. While an approximate amount of $2.5 \mathrm{~kg}$ of fresh tea leaf samples were collected from each selected location around the UTE, a total of $4(\times 3)$ soil samples were also collected from three different depths, 0 to $5 \mathrm{~cm}, 6$ to $12 \mathrm{~cm}$ and 13 to $20 \mathrm{~cm}$, of 
the corresponding locations to the tea leaves samples. More specifically, the soil samples were collected from four different points within an area of $1 \mathrm{~m}^{2}$ around the tea tree. The 25-year-old tea trees were selected for collection of the tea leaf samples. Usually, the branches of the tea plant are cut and are fertilized twice per year, and in some cases fertilizers are used more than twice for influencing the growth of the tea plant in the garden. At present, the UTE produces approximately 0.7 million tons of tea per year with six separate grades of tea including the export quality one. In the local market and throughout the country, this estate supplies one of the popular tea brands "Mostafa tea". Five marketed tea leaf samples were also collected from the local market, allowing comparison of the measured radioactivity from these with that from the fresh tea leaves collected from the UTE.

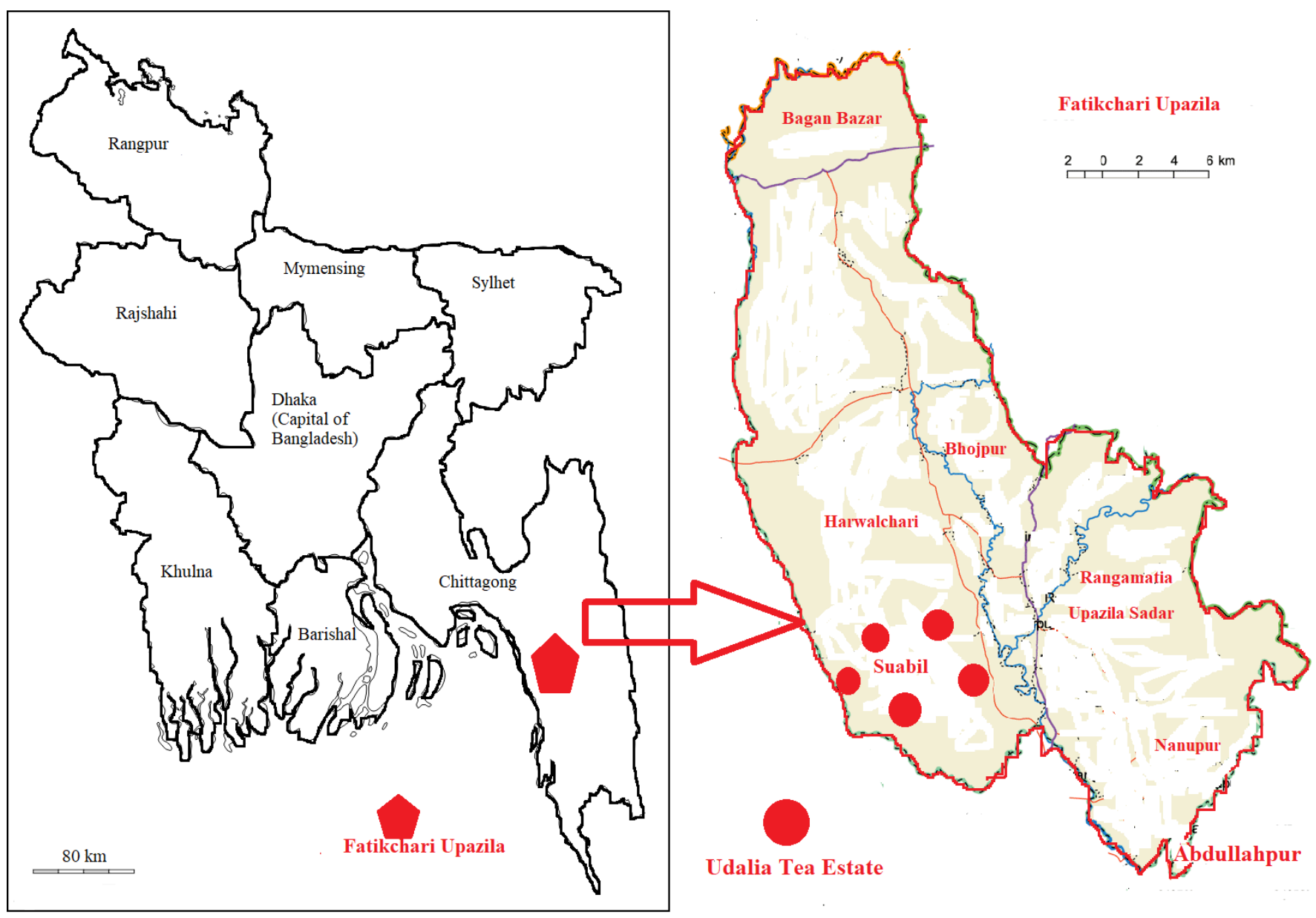

Figure 1. Location of the Udalia Tea Estate at the Fatikchari Upazila of the Chittagong district in Bangladesh.

The procedure for sample collection followed that recommended by the IAEA [4]. The collected samples were stored separately in sealed plastic bags and tagged with an identification number, and with the date and location of sampling. The samples were dried under direct sunlight for several days to allow evaporation of moisture content, subsequently being further dried for a period of $24 \mathrm{~h}$ in an oven maintained at $85{ }^{\circ} \mathrm{C}$ to remove any remaining moisture. The dried samples were then mechanically crushed into a fine powder, homogenized with a mortar and pestle and filtered through a sieve of $0.395 \mathrm{~mm}$ mesh size to obtain similarly sized particles. A constant dry weight was measured out for each sample evaluation. For the determination of activity concentration, the dried sample was transferred to an individual cylindrical container having dimension of $3.5 \mathrm{~cm}$ height and $8.5 \mathrm{~cm}$ diameter. To settle and obtain a homogeneous mixture of the samples, the containers were simply shaken by hand. The containers were then sealed 
tightly by using an insulating tape to reduce the possibility of moisture contamination. The samples were then kept undisturbed for 5-7 weeks at room temperature to attain secular equilibrium between short-lived progeny with the respective long-lived parents, ${ }^{226} \mathrm{Ra}$ (from ${ }^{238} \mathrm{U}$ ) and ${ }^{228} \mathrm{Ra}$ (from ${ }^{232} \mathrm{Th}$ ) [38,39]. It was assumed that ${ }^{222} \mathrm{Rn}$ and ${ }^{220} \mathrm{Rn}$ could not escape from the sealed containers during the period of storage. The samples were then ready for subsequent measurement and analysis by $\gamma$-ray spectrometry.

\subsection{Measurement of Radionuclides}

This study used a co-axial high-purity germanium (HPGe) $\gamma$-ray detector (GC2018, CANBERRA, USA), having a relative efficiency of $20 \%$, resolution of $1.8 \mathrm{keV}$ at $1332 \mathrm{keV}$ of peak of ${ }^{60} \mathrm{Co}$ source, to measure the samples and standards obtained from the IAEA. The detector was coupled with a digital spectrum analyzer and GENIE 2000 to acquire the $\gamma$-ray spectra emitted from the samples. To ensure a low background environment, a cylindrical lead shielded arrangement (5.08 cm thick) with fixed bottom and movable cover was installed. The efficiency of the detector was measured using the reference samples RGU-1, RGTh-1 and RGK-1 provided by the IAEA [40], with results as presented in Figure 2. The standard sources containing known concentrations of ${ }^{226} \mathrm{Ra},{ }^{232} \mathrm{Th}$ and ${ }^{40} \mathrm{~K}$ were supplied by the Canada Center for Mineral and Energy Technology (CAMET) under a contract with the IAEA. Considering the leaves' texture and density, a radioactive standard with leafy vegetables was prepared by mixing/spiking ${ }^{226} \mathrm{Ra}$ standard source of solid matrices in identical containers to the samples, and using them accordingly. Necessary information on the calibration of the efficiency of the detector is available elsewhere [41]. In this study, each sample was measured for 10,000 seconds to achieve reasonable statistics. The net count rate from the primordial radionuclides originating from the samples was obtained by subtracting the background count from the gross count, both acquired for the same counting time. The activity concentrations of ${ }^{226} \mathrm{Ra}$ and ${ }^{232} \mathrm{Th}$ radionuclides were assessed using the characteristic gamma lines of their short-lived progeny [42,43]. The concentrations of ${ }^{40} \mathrm{~K}$ and ${ }^{137} \mathrm{C}$ s were determined by the gamma ray lines of $1460.77 \mathrm{keV}$ and $661 \mathrm{keV}$, respectively. For evaluation of ${ }^{226} \mathrm{Ra}$ and ${ }^{232} \mathrm{Th}$, a weighted mean approach was applied following reference [14].

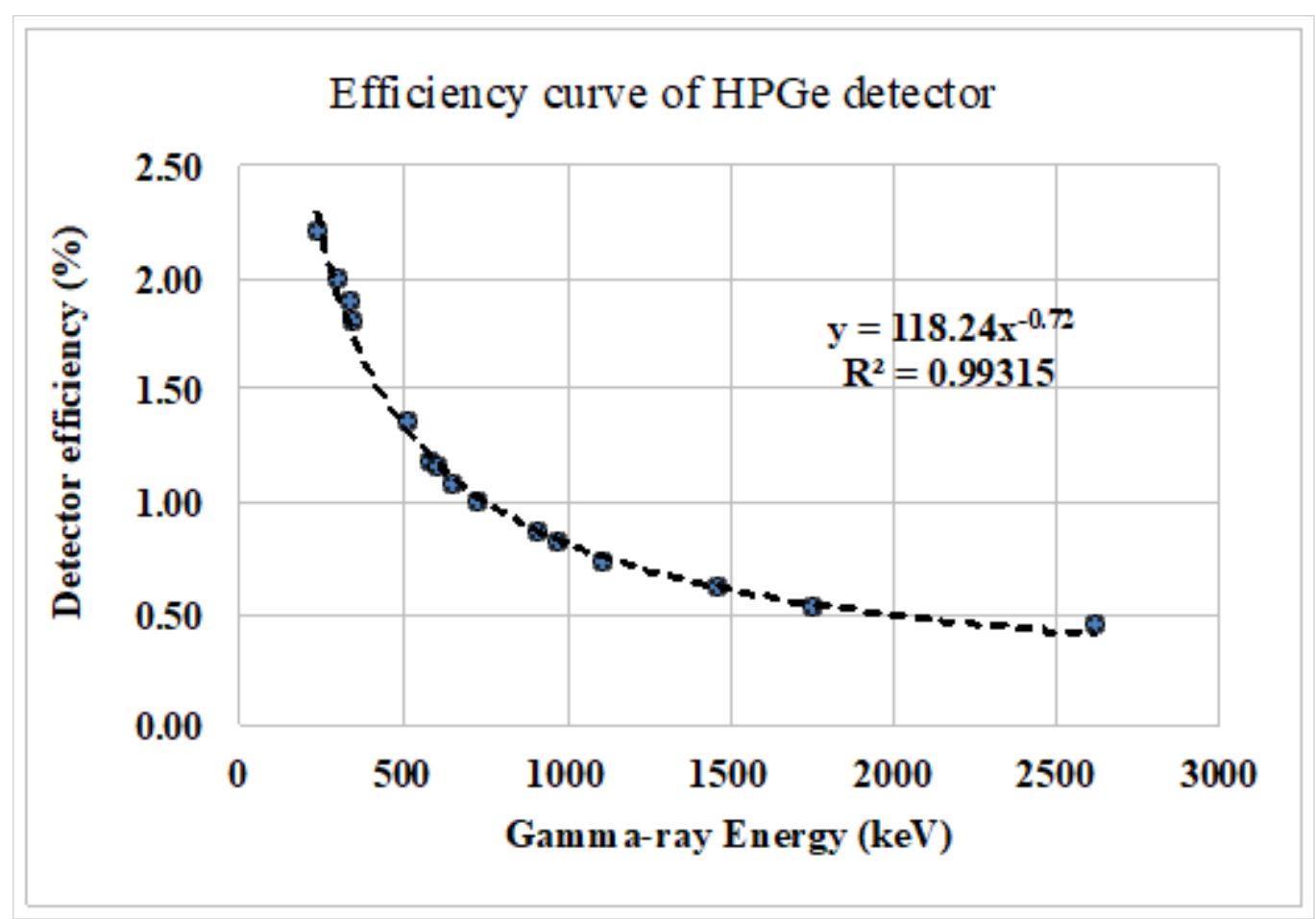

Figure 2. Counting efficiency curve of the HPGe (high-purity germanium) detector. 


\subsection{Calculation of Activity Concentration}

Activity concentrations of radionuclides $\left(\mathrm{Bq} \mathrm{kg}^{-1}\right)$ in surface soil, sub-surface soils and plant samples were calculated using Equation (1) [41]:

$$
\text { Activity concentration }=\frac{\mathrm{CPS} \times 100 \times 1000}{\varepsilon_{f}(\%) \cdot \times I_{\gamma} \times w_{\mathcal{S}}(\mathrm{kg})}
$$

where CPS represents the net counts per second, $\varepsilon_{f}$ the efficiency of the detector, $I \gamma$ the branching ratio and $W_{s}$ the weight of the sample in $\mathrm{kg}$. The statistical uncertainties were expressed in terms of standard deviation $( \pm \sigma)$, where $\sigma$ is expressed in Equation (2) [41]:

$$
\sigma=\sqrt{\left[\frac{N_{s}}{T_{s}^{2}}+\frac{N_{b}}{T_{b}^{2}}\right]}
$$

where $N_{s}$ and $N_{b}$ represent the sample and background counts in time $T_{s}$ and $T_{b}$, respectively. The total uncertainty for each measured sample was calculated taking into account the statistical and other components of uncertainty. The combined uncertainty of the activity was estimated by using the quadratic sum of relevant quantities, which can be defined by Equation (3) [44]:

$$
\Delta A=A \times \sqrt{\left(\frac{\Delta N}{N}\right)^{2}+\left(\frac{\Delta \varepsilon_{\gamma}}{\varepsilon_{\gamma}}\right)^{2}+\left(\frac{\Delta \rho_{\gamma}}{\rho_{\gamma}}\right)^{2}+\left(\frac{\Delta m_{s}}{M_{s}}\right)^{2}}
$$

where $\Delta A$ is the combined uncertainty of each measured value. The symbols $\Delta N, \Delta \varepsilon_{\gamma}$, $\Delta \rho_{\gamma}$ and $\Delta m_{s}$ represent the uncertainties due to the counting statistics, $N(<7 \%)$, detection efficiency, $\varepsilon_{\gamma}(4 \%)$, gamma ray emission probability, $\rho_{\gamma}(<1 \%)$, and sample weight, $M_{S}$ $(<2 \%)$, respectively. The determined radioactivity levels, together with the uncertainties, are presented in Table 1.

\begin{tabular}{|c|c|c|c|c|c|c|c|c|c|}
\hline \multirow{2}{*}{ Sampling Location } & \multirow{2}{*}{ Sample Type } & \multicolumn{4}{|c|}{$\begin{array}{l}\text { Activity Concentrations }\left(\mathrm{Bq} \mathrm{kg}^{-1}\right) \text { Together } \\
\text { with Uncertainty }\end{array}$} & \multicolumn{4}{|c|}{ Transfer Factor } \\
\hline & & ${ }^{226} \mathrm{Ra}$ & ${ }^{232} \mathrm{Th}$ & ${ }^{40} \mathrm{~K}$ & ${ }^{137} \mathrm{Cs}$ & ${ }^{226} \mathrm{Ra}$ & ${ }^{232} \mathrm{Th}$ & ${ }^{40} \mathrm{~K}$ & ${ }^{137} \mathrm{Cs}$ \\
\hline \multirow{2}{*}{ Location-1 } & Garden Tea & $5.7 \pm 0.6$ & $4.4 \pm 0.5$ & $190 \pm 31$ & $<0.4$ & \multirow{2}{*}{$0.13 \pm 0.08$} & \multirow{2}{*}{$0.09 \pm 0.05$} & \multirow{2}{*}{$0.69 \pm 0.39$} & \multirow{2}{*}{-} \\
\hline & Soil & $45 \pm 3$ & $51 \pm 1$ & $275 \pm 80$ & $8.5 \pm 1$ & & & & \\
\hline \multirow{2}{*}{ Location-2 } & Garden Tea & $3.6 \pm 0.7$ & $3.2 \pm 0.4$ & $258 \pm 29$ & $<0.4$ & \multirow{2}{*}{$0.11 \pm 0.08$} & \multirow{2}{*}{$0.05 \pm 0.04$} & \multirow{2}{*}{$0.41 \pm 0.13$} & \multirow{2}{*}{-} \\
\hline & Soil & $34 \pm 9$ & $63 \pm 5$ & $635 \pm 35$ & $7 \pm 1$ & & & & \\
\hline \multirow{2}{*}{ Location-3 } & Garden Tea & $5.7 \pm 1.0$ & $2.4 \pm 0.5$ & $175 \pm 32$ & $<0.4$ & \multirow{2}{*}{$0.15 \pm 0.06$} & \multirow{2}{*}{$0.05 \pm 0.01$} & \multirow{2}{*}{$0.55 \pm 0.16$} & \multirow{2}{*}{-} \\
\hline & Soil & $37 \pm 7$ & $50 \pm 13$ & $391 \pm 73$ & $9 \pm 1$ & & & & \\
\hline \multirow{2}{*}{ Location-4 } & Garden Tea & $3.6 \pm 0.6$ & $5.8 \pm 0.9$ & $136 \pm 22$ & $<0.4$ & \multirow{2}{*}{$0.10 \pm 0.03$} & \multirow{2}{*}{$0.09 \pm 0.02$} & \multirow{2}{*}{$0.36 \pm 0.13$} & \multirow{2}{*}{ - } \\
\hline & Soil & $36 \pm 7$ & $65 \pm 21$ & $373 \pm 73$ & $4 \pm 1$ & & & & \\
\hline \multirow{2}{*}{ Location-5 } & Garden Tea & $4.1 \pm 0.8$ & $5.8 \pm 1.1$ & $132 \pm 25$ & $<0.4$ & \multirow{2}{*}{$0.10 \pm 0.03$} & \multirow{2}{*}{$0.10 \pm 0.04$} & \multirow{2}{*}{$0.54 \pm 0.12$} & \multirow{2}{*}{-} \\
\hline & Soil & $42 \pm 12$ & $50 \pm 19$ & $245 \pm 30$ & $3 \pm 1$ & & & & \\
\hline Mean & & & & & & $0.12 \pm 0.08$ & $0.08 \pm 0.05$ & $0.46 \pm 0.35$ & - \\
\hline
\end{tabular}

Table 1. Concentrations of ${ }^{226} \mathrm{Ra},{ }^{232} \mathrm{Th},{ }^{40} \mathrm{~K}$ and ${ }^{137} \mathrm{Cs}$ in the analyzed soil and tea leaf samples (both fresh and marketed tea leaves) and calculated transfer factors from soil-to-tea leaf (fresh tea leaves from UTE (Udalia Tea Estate)).

The lower limit of detection or the minimum detectable activity concentration (MDA) of the measurement system was calculated using Equation (4) $[45,46]$ :

$$
\mathrm{MDA}=\frac{k_{\alpha} \times \sqrt{\beta}}{\varepsilon_{\gamma} \times \rho_{\gamma} \times T_{s} \times M_{s}}
$$


where $K_{\alpha}$ represents the statistical coverage factor which is equal to 1.64 (at the $95 \%$ confidence level), $\beta$ is the background count in the energy of interest and the other symbols $\varepsilon_{\gamma}, \rho_{\gamma}, T_{S}$ and $M_{S}$ represent detection efficiency, gamma-ray emission probability, counting time, and sample weight, respectively. The MDAs for the studied radionuclides ${ }^{226} \mathrm{Ra}$, ${ }^{232} \mathrm{Th},{ }^{40} \mathrm{~K}$ and ${ }^{137} \mathrm{Cs}$ were calculated to be $0.32 \mathrm{~Bq} \mathrm{~kg}^{-1}, 0.60 \mathrm{~Bq} \mathrm{~kg}^{-1}, 2.5 \mathrm{~Bq} \mathrm{~kg}{ }^{-1}$ and $0.4 \mathrm{~Bq} \mathrm{~kg}^{-1}$, respectively.

\subsection{Soil to Tea Leaves Transfer Factor (TF)}

Within the food we eat, plants are the principal recipients of radioactive contamination, a result of atmospheric or other releases of radionuclides and from naturally occurring radioactivity within the soil [40]. Basically, the transfer factor defines the uptake of radionuclides from soil to plants, which can be calculated by the ratio of the radioactivity per unit dry weight of plant $\left(C_{P}\right)$ to the radioactivity per unit dry weight of soil $\left(C_{S}\right)$ in the rooting zone, using the Equation (5) [47,48]:

$$
\mathrm{TF}=\frac{C_{P}}{C_{S}}
$$

Dry weight analysis is preferred, the amount of radioactivity per kilogram dry weight being subject to much less variability than the amount per unit fresh weight, thereby reducing uncertainties in the measured TF (transfer factor) [49]. The calculated TFs for the studied tea leaf samples are shown in Table 1.

\subsection{Annual Committed Effective Dose (ACED)}

Following the consumption characteristics of foodstuffs, the committed effective dose due to the ingestion of radionuclides can be calculated using Equation (6), as below [50]:

$$
\operatorname{AECD}(\mu \mathrm{Sv} / \mathrm{y})=C_{r} \times \sum_{i=1}^{3} D_{c f i} \times A_{i}
$$

where $C_{r}$ is the intake of radionuclides through use of the tea leaves, $D_{C F, i}$ are the ingestion dose conversion coefficients of $2.8 \times 10^{-7} \mathrm{~Sv} \mathrm{~Bq}^{-1}, 2.2 \times 10^{-7} \mathrm{~Sv} \mathrm{~Bq}^{-1}$ and $6.2 \times 10^{-9}$ Sv Bq ${ }^{-1}$ for ${ }^{226} \mathrm{Ra},{ }^{232} \mathrm{Th}$ and ${ }^{40} \mathrm{~K}$, respectively, for an adult [51] and $\mathrm{A}_{\mathrm{i}}$ is the measured activity concentration (Bq. $\mathrm{kg}^{-1}$ ) of each radionuclide. According to the typical statistics, an average of $2 \mathrm{~g}$ of tea leaves is needed to prepare a cup of tea and if one person drinks two cups of tea per day, then an amount of some $1.5 \mathrm{~kg} /$ year is consumed by an individual. The two cups of tea is a typical tea consumption characteristic for the Bangladeshi population. The $C_{r}$ is also defined as the consumption rate.

\subsection{Threshold Consumption Rate of Tea $(\mathrm{kg} / \mathrm{y})$}

The threshold consumption rate $\left(D I_{\text {thresh }}\right)$ represents a reference dietary level to avoid deleterious health hazards due to the intake of radionuclides via foodstuffs [52]. The particular threshold data due to the drinking of tea can be estimated by using the following Equation (7) [53]:

$$
D I_{\text {thresh }}(\mathrm{kg} / \mathrm{y})=\frac{E_{\text {ave }}}{\sum_{i=1}^{3} D_{c f i} \times A_{i}}
$$

were $E_{\text {ave }}(290 \mu \mathrm{Sv} / \mathrm{y})$ is the threshold committed effective dose due to the ingestion of radionuclides of interest via the consumption of foodstuffs [54,55], $A_{1}, A_{2}$ and $A_{3}$ are the activity concentrations of ${ }^{226} \mathrm{Ra},{ }^{232} \mathrm{Th}$ and ${ }^{40} \mathrm{~K}$, respectively, in the tea leaf samples and $D_{c f i}$ is the activity to dose conversion coefficient for the radionuclides of interest, as before.

\subsection{Carcinogenic Risk}

The carcinogenic risk for a population is estimated by assuming a linear no threshold, dose-effect relationship as per ICRP practice. For low doses, the ICRP suggest a fatal cancer 
risk factor of $0.05 \mathrm{~Sv}^{-1}$ [56], which indicates that the probability of a person dying of cancer is increased by $5 \%$ for a total dose of $1 \mathrm{~Sv}$ received during a lifetime. The estimated average annual committed effective dose for tea leaves is used herein to calculate the carcinogenic risk for an adult, made of the following relationship Equation (8):

$$
E l C R=\operatorname{AECD}(\mu S v / y) \times R_{f}\left(S v^{-1}\right) \times A_{l s}(y)
$$

where $R_{f}$ is the risk factor per sievert of annual effective dose received by the consumption of tea and $A_{l s}$ is the cumulated time of tea consumption by Bangladeshi populace. Considering the local typical tea consumption characteristics, a duration of 50 years was used for both sexes.

\section{Results and Discussion}

\subsection{Activity Concentration in the Tea Garden Doil Samples}

The mean activity concentrations of ${ }^{226} \mathrm{Ra},{ }^{232} \mathrm{Th},{ }^{40} \mathrm{~K}$ and ${ }^{137} \mathrm{Cs}$ in the soil samples collected from five locations of UTE are given in Table 1. The measured values in the investigated soil samples are found in the order ${ }^{40} \mathrm{~K}>{ }^{232} \mathrm{Th}>{ }^{226} \mathrm{Ra}>{ }^{137} \mathrm{Cs} .{ }^{40} \mathrm{~K}$ dominates over the other nuclides, which is not unexpected. This is because potassium is the seventh most abundant element in the Earth's crust, making up 2.6\% of the weight of the earth's crust [57]. The greater activity concentration of ${ }^{232} \mathrm{Th}$ over that of ${ }^{226} \mathrm{Ra}$ may be attributed to the differences in the physical and chemical characteristics in a natural environment. In the earth's crust, both uranium and thorium tend to occur together due to the some inherent characteristics. However, throughout the various superficial processes like weathering and transportation, and the soil characteristics ( $\mathrm{pH}$ and redox), they become fractionated. In general, thorium possesses low solubility and accumulates on particular phases whereas uranium is chemically more soluble and mobile. Consequently, uranium can easily be redistributed and transported in various environmental matrices compared to thorium [48].

Table 1 shows the mean activity concentrations of ${ }^{226} \mathrm{Ra}$ in soil samples for all locations other than that at location 2 to be greater than the UNSCEAR reported worldwide mean value of $35 \mathrm{~Bq} \cdot \mathrm{kg}^{-1}$ [49]. Among the three studied layers/depths of soil, the greatest concentration of ${ }^{226} \mathrm{Ra}\left(53 \pm 8 \mathrm{~Bq} \cdot \mathrm{kg}^{-1}\right)$ was at location 5 , at a depth of $13-$ to $20 \mathrm{~cm}$, whereas, the minimum concentration of ${ }^{226} \mathrm{Ra}\left(27 \pm 7 \mathrm{~Bq} \cdot \mathrm{kg}^{-1}\right)$ was at location 2 , at a depth of 6 to $12 \mathrm{~cm}$. This may be correlated to the ambient environment, i.e., the presence of high moisture content in the clay silty sand soil of this location which allows better solubility of ${ }^{226} \mathrm{Ra}[58]$.

For all locations the mean activity concentrations of ${ }^{232} \mathrm{Th}$ are greater than the worldwide mean value of $30 \mathrm{~Bq} \cdot \mathrm{kg}^{-1}$ [49], while the ${ }^{40} \mathrm{~K}$ data for all locations other than location 2 are less than the UNSCEAR [49] reported mean concentration of $400 \mathrm{~Bq} \cdot \mathrm{kg}^{-1}$. In respect to the vertical distribution, the greatest concentration of ${ }^{232} \mathrm{Th}\left(82 \pm 11 \mathrm{~Bq} \cdot \mathrm{kg}^{-1}\right)$ was in soil from location 4 , at a depth of 6 to $12 \mathrm{~cm}$, whereas the minimum ${ }^{232} \mathrm{Th}$ concentration (29 \pm 7 Bq. $\mathrm{kg}^{-1}$ ) was from soil at location 5 , at a depth of 0 to $5 \mathrm{~cm}$. Soil samples from location 5 are clay silty sand and have large carbonate content, a matter correlating with the low ${ }^{232} \mathrm{Th}$ concentration. The data show the level of natural radioactivity forming a similar distribution in the surface and deep layered soils.

The greatest concentration of ${ }^{40} \mathrm{~K}\left(672 \pm 81 \mathrm{~Bq} \cdot \mathrm{kg}^{-1}\right)$ was shown to be at location 2, at a depth of 6 to $12 \mathrm{~cm}$, whereas the minimum ${ }^{40} \mathrm{~K}$ concentration $\left(201 \pm 78 \mathrm{~Bq} \cdot \mathrm{kg}^{-1}\right)$ was at location 1, at a depth of 6 to $12 \mathrm{~cm}$. The majority of ${ }^{40} \mathrm{~K}$ is a part of a clay mineral component rather than organic matter and its mobility depends on its solubility in the soil [59]. The low concentration of ${ }^{40} \mathrm{~K}$ may be correlated to the soil texture, i.e., the presence of more sandy soil. Moreover, use of NPK fertilizer at least two times per year for better yield of leaves may contribute to the higher values of ${ }^{40} \mathrm{~K}$ activity [60,61].

${ }^{137} \mathrm{Cs}$, an anthropomorphic nuclide, as detected in trace amounts in the UTE soil, predominantly in the topsoil layers and less so or otherwise not detectable in sub-surface layers. The greatest ${ }^{137} \mathrm{Cs}$ mean activity concentration, at $10 \pm 1 \mathrm{~Bq} \cdot \mathrm{kg}^{-1}$, was found 
in surface soil at location 1 , at a depth of 0 to $5 \mathrm{~cm}$, while the lowest concentration of $3 \pm 1 \mathrm{~Bq} \cdot \mathrm{kg}^{-1}$ was found at location 5 , at the same depth. ${ }^{137} \mathrm{Cs}$ in other locations was not detected, the one exception being at location 1, at a depth of 6 to $12 \mathrm{~cm}$. The mean ${ }^{137} \mathrm{C}$ s concentrations at the different locations were found to be less than the world average value $51 \mathrm{Bqkg}^{-1}$ as reported by UNSCEAR [49]. The ${ }^{137} \mathrm{Cs}$ is a quasi-permanent source of external gamma ray exposure, the activity slowly decaying in accordance with a half-life of some 30 years. The small likelihood that this nuclide will form a significant soil to plant pathway is generally acknowledged, the contaminant for the most part being linked to widely publicized nuclear establishment accidents. When detected, most typically at very low levels, the variation in the activity concentrations of the radionuclides are due to meteorological factors, the difference in sampling depth, physiochemical soil characteristics and the time of deposition.

\subsection{Activity Concentration in Tea Leaf Samples}

The measured activity concentrations of ${ }^{226} \mathrm{Ra},{ }^{232} \mathrm{Th},{ }^{40} \mathrm{~K}$ and ${ }^{137} \mathrm{C}$ s radionuclides in tea leaf samples collected from the Udalia Tea Estate as well as from the local market are summarized in Table 1. The concentrations of radionuclides in tea leaf samples are reported in Bq. $\mathrm{kg}^{-1}$ dry weight. The activity concentrations of studied radionuclides in the investigated tea leaf samples were in the order ${ }^{40} \mathrm{~K}>{ }^{226} \mathrm{Ra}>{ }^{232} \mathrm{Th}>{ }^{137} \mathrm{Cs}$. The activity concentrations of ${ }^{226} \mathrm{Ra}$ were found to be greater than that of ${ }^{232} \mathrm{Th}$ in most of the tea leaf samples collected from UTE. One probable reason is that the ${ }^{238} \mathrm{U}\left({ }^{226} \mathrm{Ra}\right)$ tends to move towards the outer extremities of the tree and accumulates more greatly in new leaves and sprouts [62].

The greater concentration of ${ }^{40} \mathrm{~K}$ in tea leaf samples can be attributed for the most part to the specific metabolic processes of potassium involved in plant growth. Furthermore, for faster plant growth, the extra use of muriate (potassium chloride) of potassium fertilizer may be another factor causing the increase of ${ }^{40} \mathrm{~K}$ concentration in the tea leaf samples [60]. It has been reported that about $88-96 \%$ of $\mathrm{K}$ is taken up by the plant from the soil through the root system [61]. Since plants take up a high amount of potassium and natural potassium contains $0.0117 \%$ of ${ }^{40} \mathrm{~K}$, the detection of high level of ${ }^{40} \mathrm{~K}$ in plants is not unexpected.

\subsection{Transfer Factors (TF) of Radionuclides from Soil-to-Tea Leaf}

Soil to tea leaf transfer factor (TF) values from the five different locations are also presented in Table 1, the values depending on soil properties such as nutrient and moisture contents and $\mathrm{pH}$ [51]. It can be observed from the results that the TF values for ${ }^{226} \mathrm{Ra},{ }^{232} \mathrm{Th}$ and ${ }^{40} \mathrm{~K}$ lie within the range $1.1 \times 10^{-2}$ to 1.0 , in accordance with values reported by the IAEA [63]. ${ }^{137} \mathrm{Cs}$ in all of the tea leaf samples was found to be below the detection limit, therefore the transfer factors could not be calculated. Note that the IAEA report a TF range of $0.02-3.2$ for ${ }^{137} \mathrm{Cs}$ [63]. This indicates that, compared to ${ }^{226} \mathrm{Ra},{ }^{232} \mathrm{Th}$ and ${ }^{40} \mathrm{~K},{ }^{137} \mathrm{Cs}$ is less efficiently transported from soil to the tea bush, as well as to the leaves

The transfer factors in the studied tea leaves are in the order ${ }^{40} \mathrm{~K}>{ }^{226} \mathrm{Ra}>{ }^{232} \mathrm{Th}$ $>{ }^{137} \mathrm{Cs}$, that for ${ }^{40} \mathrm{~K}$ being significantly greater than those of other radionuclides in all samples. It is well known that $\mathrm{K}$ is a very essential nutrient for plants metabolism and depending upon the particular metabolism a variable amount of $\mathrm{K}$ is taken up by plants from soil. Since elemental potassium is homeostatically controlled by the body (intake and excretion maintaining balance), such amounts of ${ }^{40} \mathrm{~K}$ in tea leaves are not to be considered to be of any particular concern as a potential radiation hazard. The actual concentration of radium in plant species clearly depends on the radium content of soil, its uptake by the plants species and also the metabolic characteristics of the plants [14]. Moreover, the chemical factors such as the presence of exchangeable amount of calcium in the soil may influence the absorption rate of radium by the plants [64]. The calculated TF show mean values of less than 1 for all radionuclides. It is worth mentioning that a value of TF $>1$ is indicative of radiation hazards to human health via the soil-plant-human body pathway. 
On the other hand, a TF $=1$ would be indicative of a particular species or plant forming a useful natural process for decontamination of soil affected by a nuclear accident or deliberate nuclear device testing.

Table 2 shows a comparison of results from the present study with reported data for tea leaves from the Chittagong region of Bangladesh. Considering the similar geographical conditions, humidity and quality of soil, comparability of data might thus be expected. Within the Chittagong region, there are 17 tea growing estates in Fatickchari, 3 in Rangunia and 1 in Banskhali. In this respect, Table 2 shows the measured radioactivity of ${ }^{226} \mathrm{Ra}$ to be similar to the available literature data, while UTE values for ${ }^{232} \mathrm{Th}$ and ${ }^{40} \mathrm{~K}$ show much lower values compared to the reported data in the literature. Moreover, radioactivity in the estate tea leaves from Rize in Turkey also show higher values than the present results from UTE. The activity concentration of the artificial ${ }^{137} \mathrm{Cs}$ radionuclide for the UTE sample is shown to be below the detection limit $(<0.4)$, while a substantial amount of ${ }^{137} \mathrm{Cs}$ was reported in estate tea leaf samples from Turkey. Such a result indicates the contamination of sampling area via some known/unknown nuclear activities. There are no available studies on the radioactivity of marketed tea samples in Bangladesh, therefore studies on marketed tea leaf samples imported from abroad have been chosen for comparison. The average activity concentration of ${ }^{226} \mathrm{Ra}$ and ${ }^{232} \mathrm{Th}$ and ${ }^{40} \mathrm{~K}$ in tea leaf samples collected from the local market show greater values than the reported data from Turkey (except ${ }^{40} \mathrm{~K}$ ) and Serbia. The fact that the concentrations of ${ }^{226} \mathrm{Ra},{ }^{232} \mathrm{Th}$ and ${ }^{40} \mathrm{~K}$ vary substantially across the various regions depends mainly on their concentrations in the bedrock from which the soil originates [65].

Table 2. Average activity concentrations of ${ }^{226} \mathrm{Ra},{ }^{232} \mathrm{Th},{ }^{40} \mathrm{~K}$ and ${ }^{137} \mathrm{Cs}$ in tea leaf samples from various countries compared with that from present work.

\begin{tabular}{|c|c|c|c|c|c|c|}
\hline \multirow{2}{*}{ Sample Type } & \multirow{2}{*}{ Countries } & \multicolumn{4}{|c|}{ Activity Concentrations (Bq. $\mathrm{kg}^{-1}$ ) Together with Uncertainties } & \multirow{2}{*}{ References } \\
\hline & & ${ }^{226} \mathrm{Ra}$ & ${ }^{232} \mathrm{Th}$ & ${ }^{40} \mathrm{~K}$ & ${ }^{137} \mathrm{Cs}$ & \\
\hline \multirow{6}{*}{ Fresh tea leaf } & $\begin{array}{c}\text { UTE, } \\
\text { Chittagong, } \\
\text { Bangladesh }\end{array}$ & $4.53 \pm 0.62$ & $4.31 \pm 0.58$ & $178 \pm 28$ & $<0.4$ & Present study \\
\hline & $\begin{array}{c}\text { Chittagong } \\
\text { district, } \\
\text { Bangladesh }\end{array}$ & 5.34 & 10.07 & 429.91 & Not measured & [66] \\
\hline & $\begin{array}{c}\text { Ramgarh, } \\
\text { Bangladesh }\end{array}$ & $3.20 \pm 2.18$ & $4.65 \pm 1.76$ & $625 \pm 62.37$ & Not measured & [66] \\
\hline & $\begin{array}{c}\text { Kodala, } \\
\text { Bangladesh }\end{array}$ & $3.56 \pm 0.69$ & $27.22 \pm 3.65$ & $1243 \pm 83.91$ & Not measured & {$[66]$} \\
\hline & $\begin{array}{c}\text { Chandpur } \\
\text { Belgaon, } \\
\text { Bangladesh }\end{array}$ & $5.67 \pm 2.16$ & $12.41 \pm 2.82$ & $380 \pm 62.06$ & Not measured & [66] \\
\hline & Rize, Turkey & $36.3 \pm 6.1$ & $23.1 \pm 4.8$ & $688.4 \pm 18.3$ & $20.9 \pm 3.8$ & [67] \\
\hline \multirow{7}{*}{ Market tea leaf } & Mostafa-1 & $3.8 \pm 0.4$ & $6.0 \pm 0.7$ & $321 \pm 35$ & $<0.4$ & \multirow{4}{*}{ Present study } \\
\hline & Ceylon & $4.3 \pm 0.3$ & $4.3 \pm 0.5$ & $244 \pm 31$ & $<0.4$ & \\
\hline & Ispahani & $4.0 \pm 0.1$ & $3.9 \pm 0.5$ & $159 \pm 32$ & $<0.4$ & \\
\hline & Taza & $5.4 \pm 0.6$ & $2.8 \pm 0.6$ & $141 \pm 29$ & $<0.4$ & \\
\hline & Mostafa & $4.3 \pm 0.3$ & $5.5 \pm 0.8$ & $183 \pm 25$ & $<0.4$ & \\
\hline & $\begin{array}{c}\text { Turkey-2 } \\
\text { (Market tea) }\end{array}$ & 0.9 & 2.7 & 501 & - & [68] \\
\hline & $\begin{array}{c}\text { Serbia-1 } \\
\text { (Market tea) }\end{array}$ & $0.6-8.2$ & $1.7-15.1$ & $126-1243.7$ & - & [69] \\
\hline
\end{tabular}




\subsection{Committed Effective Dose, Threshold Consumption Rate and Carcinogenic Risk}

The calculated values of committed effective dose, threshold consumption rate and carcinogenic risk are shown in Table 3. The committed effective dose due to the intake of the studied radionuclides via tea consumption was found to be in the range of 4.7-5.6 $\mu \mathrm{Sv} \mathrm{y}^{-1}$ with a mean of $5.0 \mu \mathrm{Sv}^{-1}$. This compares with an average worldwide ingestion dose of ${ }^{226} \mathrm{Ra}$ and ${ }^{232} \mathrm{Th}$ of $120 \mu \mathrm{Sv} \mathrm{y}^{-1}$ and $170 \mu \mathrm{Sv} \mathrm{y}^{-1}$ for ${ }^{40} \mathrm{~K}$, making a total annual dose estimate of $290 \mu \mathrm{Sv} \mathrm{y}^{-1}$ from the total diet [49]. The annual effective doses from the ingestion of tea leaves were found much lower than the limiting value recommended by UNSCEAR [49]. Note that the estimated $5.0 \mu \mathrm{Sv} \mathrm{y}{ }^{-1}$ is contributed to by only a single dietary element (here tea leaf), thus such a low value is not unexpected. However, the radiation risk via the cumulative consumption of tea leaf may not be totally negligible, because tea forms only a minor part of the total dietary habits [70,71]. Figure 3 shows the dose contribution due to the individual radionuclides. Among the studied radionuclides, ${ }^{226} \mathrm{Ra}$ incurred the maximum dose (38\%) followed by ${ }^{40} \mathrm{~K}(33 \%)$ and ${ }^{232} \mathrm{Th}(29 \%)$. Exposure to radioactive materials, especially radium, over a prolonged time may result in an increased carcinogenic risk. In addition, higher doses of radium are found to have links with anemia, cataracts, reduction of bone growth, etc. [72].

Table 3. Calculated hazard parameters due to the consumption of studied tea leaves collected from the UTE, Chittagong, Bangladesh.

\begin{tabular}{|c|c|c|c|c|c|c|}
\hline \multirow{2}{*}{ Sample } & \multicolumn{4}{|c|}{ Annual Effective Dose (uSv/y) } & \multirow{2}{*}{ Threshold Consumption Rate, kg/y } & \multirow{2}{*}{ Lifetime Carcinogenic Risk } \\
\hline & ${ }^{226} \mathrm{Ra}$ & ${ }^{232} \mathrm{Th}$ & ${ }^{40} \mathrm{~K}$ & Total & & \\
\hline TL-1 & 2.4 & 1.5 & 1.8 & 5.6 & 77 & $1.40 \times 10^{-5}$ \\
\hline TL-2 & 1.5 & 1.1 & 2.4 & 5.0 & 88 & $1.24 \times 10^{-5}$ \\
\hline TL-3 & 2.4 & 0.8 & 1.6 & 4.8 & 90 & $1.20 \times 10^{-5}$ \\
\hline TL-4 & 1.5 & 1.9 & 1.3 & 4.7 & 93 & $1.17 \times 10^{-5}$ \\
\hline TL-5 & 1.7 & 1.9 & 1.2 & 4.9 & 89 & $1.22 \times 10^{-5}$ \\
\hline Mean & 1.9 & 1.4 & 1.7 & 5.0 & 88 & $1.25 \times 10^{-5}$ \\
\hline
\end{tabular}

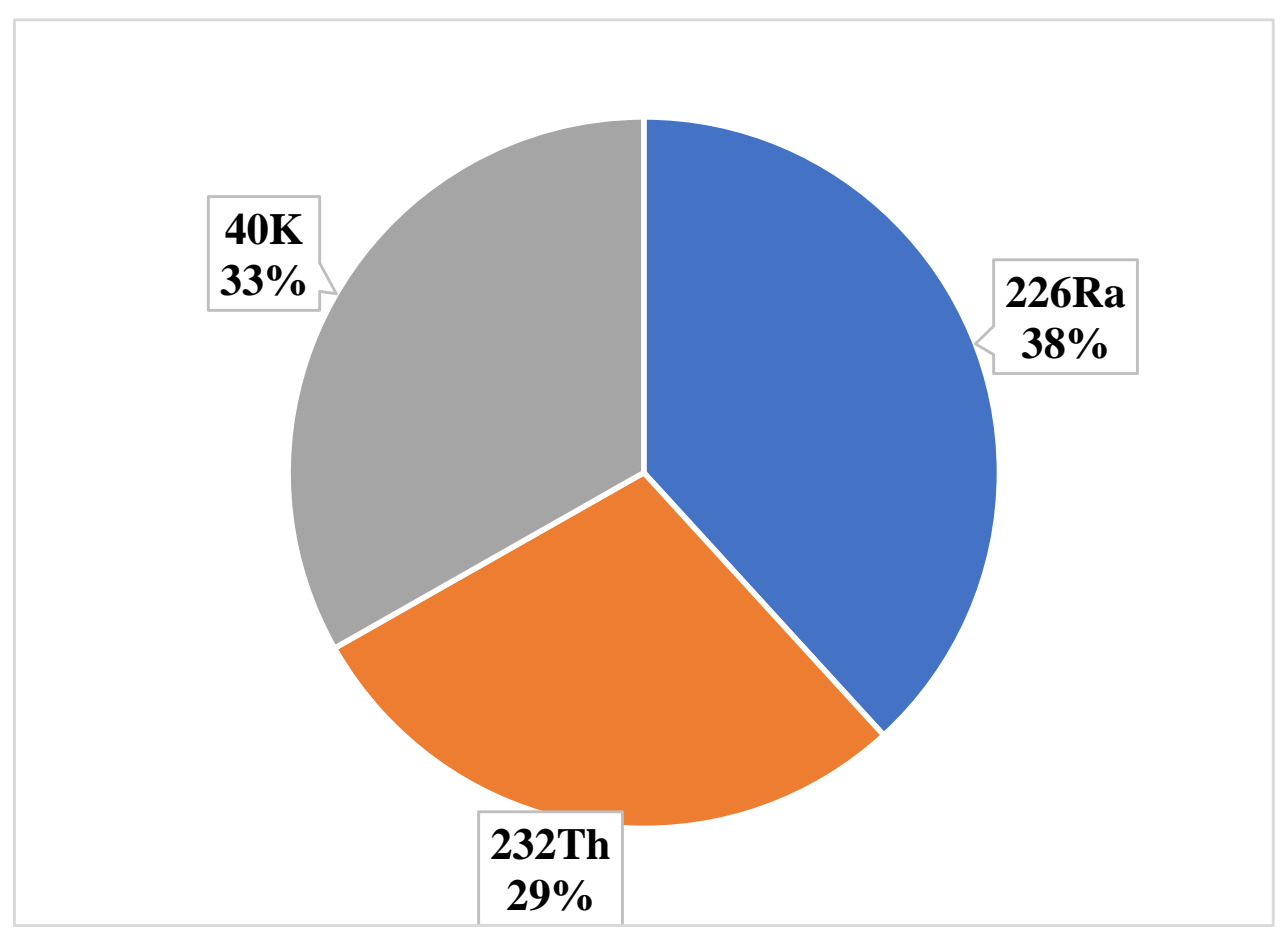

Figure 3. Dose contribution by individual radionuclides due to the consumption of tea leaves. 
The estimated mean threshold consumption rate for the studied tea leaf samples was found to be $88 \mathrm{~kg} / \mathrm{y}$ (equivalent to $241 \mathrm{~g} / \mathrm{d}$ ), an untenable value. This parameter indicates that the consumption of tea below the estimated value poses only a negligible radiological health hazard, while a greater rate than the calculated ones indicates enhanced radiological health risk.

Accordingly, the mean cumulative carcinogenic risk via tea leaf consumption (for a period of 50 years) was estimated at $1.3 \times 10^{-5}$, significantly lower than the ICRP given cancer risk of $2.5 \times 10^{-3}$, based on an annual effective dose limit of $1 \mathrm{mSv}$ for the general population [52].

\section{Conclusions}

Activity concentrations of ${ }^{226} \mathrm{Ra},{ }^{232} \mathrm{Th},{ }^{40} \mathrm{~K}$ and ${ }^{137} \mathrm{Cs}$ in soil and tea leaf samples collected from a large tea estate in the Chittagong region of Bangladesh were measured by HPGe $\gamma$-ray spectrometry. In addition, the most popular tea brands available in the local market were also measured to observe the effect of production processes. The transfer factor of radionuclides from soil to tea leaves was found to be less than 1, indicating the corresponding uptake by the tea plant to be insignificant. The estimated committed effective dose and the carcinogenic risk all show values far below the limiting ranges as suggested by various international bodies. Thus, the consumption of tea (at $4 \mathrm{~g} / \mathrm{day} / \mathrm{person}$ or two cups/day/person) produced from the Udalia Tea Estate provides an insignificant radiation risk to the health of the local populace. Considering a number of facts such as the non-availability of the literature data on TFs of the UTE tea leaves, the recommended limiting values for total dietary habits and that for the tea arising from this single entity, and that the radiation risk follows the linear no threshold model, the measured data can act as reference values for any future experimental or modelling studies for the protection of human health.

Author Contributions: Conceptualization, N.A., M.M.R., and N.S.; methodology, N.A. and M.M.R.; software, M.I.C. and M.U.K.; validation, M.M.H.M. and J.A.; formal analysis, N.A. and J.A.; investigation, N.A., M.M.R., and N.S.; resources, M.K. and M.I.C.; data curation, N.A. and M.M.H.M.; writing—original draft preparation, N.A. and J.A.; writing—review and editing, M.U.K. and D.A.B.; visualization, A.A.; supervision, M.M.R. and N.S.; project administration, M.R.I.F. and A.A.M.S.; funding acquisition, A.A. All authors have read and agreed to the published version of the manuscript.

Funding: This work was supported by the Taif University Researchers Supporting project number (TURSP-2020/163), Taif 21944, Saudi Arabia.

Institutional Review Board Statement: Not applicable.

Informed Consent Statement: Not applicable.

Data Availability Statement: All data are available in the manuscript.

Acknowledgments: Contributions from the staff of the gamma ray spectrometry laboratory of Atomic Energy Centre Chittagong are greatly acknowledged.

Conflicts of Interest: The authors declare no conflict of interest.

\section{References}

1. Allisy, A.; Henri, B. The discovery of radioactivity. In Proceedings of the Becquerrel's Legacy: A Century of Radioactivity, London, UK, 29 February-1 March 1996; Nuclear Technology Publishing: London, UK, 1996; pp. 3-10.

2. Watson, S.J.; Jones, A.L.; Oatway, W.B.; Hughes, J.S. Ionising Radiation Exposure of the UK population, Health Protection Agency, Centre for Radiation, Chemical and Environmental Hazards, Radiation Protection Division; Chilton: Didcot, UK, 2005.

3. NCRP. National Council on Radiation Protection and Measurement. Exposure of the Population in United States and Canada from Natural Background Radiation; NCRP Report No 49; National Council on Radiation: Bethesda, MD, USA, 1987.

4. Elegba, S.B.; Funtua, I.I. Naturally occurring radioactive material (NORM) assessment of oil and gas production installations in Nigeria. Int. At. Energy Agency (IAEA) 2005, 37, 256.

5. World Nuclear Association. Radiation and Nuclear Energy. 2011. Available online: http://www.world-nuclear.org/info/inf30. html (accessed on 30 December 2020). 
6. Guagliardi, I.; Rovella, N.; Apollaro, C.; Bloise, A.; De Rosa, R.; Scarciglia, F.; Buttafuoco, G. Modelling seasonal variations of natural radioactivity in soils: A case study in southern Italy. J. Earth Syst. Sci. 2016, 125, 1569-1578. [CrossRef]

7. Dhahir, M.D.; Azhar, S.A.; Ali, A.A.; Hayder, H.H. Assessment of Natural Radionuclide levels for Tea samples in Najaf. Rap Conf. Proc. 2019, 4, 57-60.

8. Guagliardi, I.; Zuzolo, D.; Albanese, S.; Lima, A.; Cerino, P.; Pizzolante, A.; Thiombane, M.; De Vivo, B.; Cicchella, D. Uranium, thorium and potassium insights on Campania region (Italy) soils: Sources patterns based on compositional data analysis and fractal model. J. Geochem. Explor. 2020, 212, 106508. [CrossRef]

9. Hassan, Y.M.; Zaid, H.M.; Guan, B.H.; Khandaker, M.U.; Bradley, D.A.; Sulieman, A.; Latif, S.A. Radioactivity in staple foodstuffs and concomitant dose to the population of Jigawa state, Nigeria. Radiat. Phys. Chem. 2021, 178, 108945. [CrossRef]

10. Khandaker, M.U.; Asaduzzaman, K.; Nawi, S.M.; Usman, A.R.; Amin, Y.M.; Daar, E. Assessment of Radiation and Heavy Metals Risk due to the Dietary Intake of Marine Fishes (Rastrelligerkanagurta) from the Straits of Malacca. PLoS ONE 2015, 10, 0128790. [CrossRef]

11. Khandaker, M.U.; Nasir, N.L.M.; Asaduzzaman, K.; Amin, Y.M.; Bradley, D.A.; Alrefae, T. Evaluation of radionuclides transfer fromsoil-to-edible flora and estimation of radiological dose to the Malaysian populace. Chemosphere 2016, 154, 528-536. [CrossRef] [PubMed]

12. Yeltepe, E.; Şahin, N.K.; Aslan, N.; Hult, M.; Ozçayan, G.; Wershofen, H.; Yucel, U. A review of the TAEA proficiency test on natural and anthropogenic radionuclides activities in black tea. Appl. Radiat. Isot. 2018, 134, 40-44. [CrossRef]

13. Khandaker, M.U.; Shuaibu, H.K.; Alklabi, F.A.A.; Alzimami, K.S.; Bradley, D.A. Study of primordial ${ }^{226} \mathrm{Ra}$, ${ }^{228} \mathrm{Ra}$, and ${ }^{40} \mathrm{~K}$ concentrations in dietary palm dates and concomitant radiological risk. Health Phys. 2019, 116, 789-798. [CrossRef] [PubMed]

14. Khandaker, M.U.; Heffny, N.A.; Amin, Y.M.; Bradley, D.A. Elevated concentration of radioactive potassium in edible algae cultivated in Malaysian seas and estimation of ingestion dose to humans. Algal Res. 2019, 38, 101386. [CrossRef]

15. Schuller, P.; Voigt, G.; Handl, J.; Ellies, A.; Oliva, L. Global weapons' fallout ${ }^{137}$ Cs in soils and transfer to vegetation in SouthcentralChile. J. Environ. Radioact. 2002, 62, 181-193. [CrossRef]

16. Alatise, O.O.; Adebesin, T.C. Assessment of Radionuclides in some Nigerian Cereals and products. J. Nat. Sci. Eng. Technol. 2019, $18,128-142$.

17. Dufresne, C.J.; Farnworth, E.R. A review of latest research findings on the health promotion properties of tea. J. Nutr. Biochem. 2001, 12, 404-421. [CrossRef]

18. Zhu, Q.Y.; Hackman, R.M.; Ensunsa, J.L.; Holt, R.R.; Keen, C.L. Antioxidative activities of oolong tea. J. Agric. Food Chem. 2002, 50, 6929-6934. [CrossRef] [PubMed]

19. Zehringer, M.; Kammerer, F.; Wagmann, M. Radionuclides in tea and their behaviour in the brewing process. J. Environ. Radioact. 2018, 192, 75-80. [CrossRef] [PubMed]

20. Karak, T.; Bhagat, R. Trace elements in tea leaves, made tea and tea infusion: A review. Food Res. Int. 2010, 43, 2234-2252. [CrossRef]

21. Zaver, N.T. Green tea and its polyphenolic catechins: Medicinal uses in cancer and noncancer applications. Life Sci. 2006, 78, 2073-2080. [CrossRef] [PubMed]

22. Phan, L.H.; Le, D.H.; Vu, T.M.; Dang, V.C.; Tran, T.T.; Chau, V.T. Natural and artificial radionuclides in tea samples determined with gamma spectrometry. J. Radioanal. Nucl. Chem. 2018, 316, 703-707.

23. Friedman, M. Overview of antibacterial, antitoxin, antiviral, and antifungal activities of tea flavonoids and teas. Mol. Nutr. Food Res. 2007, 51, 116-134. [CrossRef]

24. Korte, G.; Dreiseitel, A.; Schreier, P.; Oehme, A.; Locher, S.; Geiger, S. Tea catechins' affinity for human cannabinoid receptors. Phytomedicine 2010, 17, 19-22. [CrossRef]

25. Fujita, H.; Yamagami, T. Anti hyper cholesterolemic effect of Chinese black tea extract in human subjects with borderline hypercholesterolemia. Nutr. Res. 2008, 28, 450-456. [CrossRef]

26. Hamer, M. The beneficial effects of tea on immune function and inflammation: A review of evidence from in vitro, animal, and human research. Nutr. Res. 2007, 27, 373-379. [CrossRef]

27. Siddiqui, I.A.; Raisuddin, S.; Shukla, Y. Protective effects of black tea extract on testosterone induced oxidative damage in prostate. Cancer Lett. 2005, 227, 125-132. [CrossRef] [PubMed]

28. Khizar, H.; Hira, I.; Uzma, M.; Uzma, B.; Sobia, M. Tea and Its Consumption: Benefits and Risks. Crit. Rev. Food Sci. Nutr. 2013. [CrossRef]

29. Chow, H.; Hakim, I.; Vining, D.; Crowell, J.; Ranger-Moore, J.; Chew, W.; Celaya, C.; Rodney, S.; Hara, Y.; Alberts, D. Effects of dosing condition on the oral bioavailability of green tea catechins after single-dose administration of polyphenon E in healthy individuals. Clin. Cancer Res. 2005, 11, 4627-4633. [CrossRef]

30. Mamun, M.; Ahmed, M. Integrated pest management in tea: Prospects and future strategies in Bangladesh. J. Plant Prot. Sci. 2011, 3, 1-13.

31. Khan, A.; Biswas, A.; Saha, A.; Motalib, M. Soil properties of Lalmai hill, Shalban Bihar and Nilachal hill of greater Comilla district and its suitability for tea plantation. Tea J. Bangladesh 2012, 41, 17-26.

32. Revitalising the Tea Sector. Available online: https://thefinancialexpress.com.bd/views/revitalising-the-tea-sector-1527864045\# (accessed on 20 December 2020). 
33. Khatun, R.; Saadat, A.H.M.; Ahasan, M.M.; Akter, S. Assessment of Natural Radioactivity and Radiation Hazard in Soil Samples of Rajbari District of Bangladesh. Jahangirnagar Univ. Environ. Bull. 2013, 2, 1-8. [CrossRef]

34. Mst, N.A.; Suranjan, N.D.; Selina, Y.; Mahfuz, S.M.M.; Mizanur, R.A.F.M. Measurement of Radioactivity and Assessment of Radiological Hazards of Tea samples collected from local market in Bangladesh. J. Bangladesh Acad. Sci. 2018, 42, 171-176.

35. Islam, M.N.; Akhter, H.; Begum, M.; Kamal, M. Comprehensive Review of the Investigation of Anthropogenic and Naturally Occurring Radionuclides in Different Parts of Bangladesh. Int. J. Adv. Eng. Manag. Sci. 2018, 4, 490-495. [CrossRef]

36. Oodolia Tea Garden, an Untapped Natural Beauty Site at Fatikchhari. Available online: https://www.daily-sun.com/ arcprint/details/167547/Oodolia-Tea-Garden-an-untapped-natural-beauty-site-at-Fatikchhari/2016-09-18 (accessed on 12 February 2021).

37. Hossain, M.K.; Azad, A.K.; Alam, M.K. Assessment of natural regeneration status in a mixed tropical forest at Kaptai of Chittagong Hill Tracts (South) forest division. Chittagong Univ. J. Sci. 1999, 23, 73-79.

38. IAEA. Intercomparison Runs Reference Manuals; AQCS: Vienna, Austria, 1995.

39. ICRP. International Commission on Radiological Protection, 1983, Publication 119: Compendium of dose coefficients based on ICRP Publication 60. Ann. ICRP 1983, 41 (Suppl. 42), e1-e130.

40. IAEA. Measurement of radionuclides in food and the environment-technical reports. In Ser; IAEA: Vienna, Austria, 1983; Volume 295, pp. 5-27.

41. Abedin, M.J.; Karim, M.R.; Hossain, S.; Deb, N.; Kamal, M.; Miah, M.H.A.; Khandaker, M.U. Spatial distribution of radionuclides in agricultural soil in the vicinity of a coal-fired brick kiln. Arab. J. Geosci. 2019, 12, 1-12. [CrossRef]

42. Amin, Y.M.; Khandaker, M.U.; Shyen, A.K.S.; Mahat, R.H.; Nor, R.M.; Bradley, D.A. Radionuclide emissions from a coal-fired power plant. Appl. Radiat. Isot. 2013, 80, 109-116. [CrossRef] [PubMed]

43. Khandaker, M.U.; Jojo, P.J.; Kassim, H.A.; Amin, Y.M. Radiometric analysis of construction materials using HPGe gamma-ray spectrometry. Radiat. Prot. Dosim. 2012, 152, 33-37. [CrossRef] [PubMed]

44. Asaduzzaman, K.; Khandaker, M.U.; Amin, Y.M.; Bradley, D.A. Natural radioactivity levels and radiological assessment of decorative building materials in Bangladesh. Indoor Built Environ. 2014, 25, 1-10. [CrossRef]

45. Khandaker, M.U.; Asaduzzaman, K.; Sulaiman, A.F.; Bradley, D.A.; Isinkaye, M.O. Elevated concentrations of naturally occurring radionuclides in heavy mineral-rich beach sands of Langkawi Island, Malaysia. Mar. Pollut. Bull. 2018, 127, 654-663. [CrossRef] [PubMed]

46. Solak, S.; Turhan, S.; Ugur, F.A.; Goren, E.; Gezer, F.; Yegingil, Z. Evaluation of potential exposure risks of natural radioactivity levels emitted from building materials used in Adana, Turkey. Indoor Built Environ. 2014, 23, 594-602. [CrossRef]

47. Nurul, A.; Mashiur, R.; Masud, K.; Naziba, S.; Mantazul, I.C. Natural and anthropogenic radioactivity levels and associated radiation hazard in soil of Oodalia Tea Estate at hilly region of Fatikchari in Chittagong, Bangladesh. J. Radiat. Res. 2014, 55, 1-6.

48. Bajoga, A.; Alazemi, N.; Shams, H.; Regan, P.; Bradley, D. Evaluation of naturally occurring radioactivity across the State of Kuwait using high-resolution gamma-ray spectrometry. Radiat. Phys. Chem. 2016, 137, 203-209. [CrossRef]

49. UNSCEAR. Exposures from Natural Radiation Sources. Annex-B 2000, 9, 124-127.

50. James, J.P. Soil to leaf transfer factor for the radionuclides226Ra, 40K, 137Cs and 90Sr at Kaiga region, India. J. Environ. Radioact. 2011, 102, 1070-1077. [CrossRef] [PubMed]

51. Forkapic, S.; Vasin, I.; Mrdja, D.; Bikit, K.; Milic, S. Correlations between soil characteristics and radioactivity content of Vojvodina soil. J. Environ. Radioact. 2017, 166, 104-111. [CrossRef] [PubMed]

52. Khandaker, M.U.; Zainuddin, N.K.; Bradley, D.A.; Faruque, M.R.I.; Almasoud, F.I.; Sayyed, M.I.; Sulieman, A.; Jojo, P.J. Radiation dose to Malaysian populace via the consumption of roasted ground and instant coffee. Radiat. Phys. Chem. 2020, 173, 1-7. [CrossRef]

53. Monica, S.; Jojo, P.J.; Khandaker, M.U. Radionuclide concentrations in medicinal florae and committed effective dose through Ayurvedic medicines. Int. J. Radiat. Biol. 2020, 96, 1028-1037. [CrossRef]

54. Cember, H.; Johnson, T.E. Introduction to Health Physics, 5th ed.; McGraw-Hill: New York, NY, USA, 2009 ; pp. 1-888.

55. UNSCEAR. Sources and Effects of Ionizing Radiation. Report to the General Assembly; Scientific Annexes: New York, NY, USA, 2000.

56. Naturally Occurring Radioactive Materials (NORM IV). In Proceedings of the an International Conference, Szczyrk, Poland, 17-21 May 2004; pp. 1-584.

57. Potassium, Chemical Element. Available online: https://www.britannica.com/science/potassium (accessed on 12 February 2021).

58. OECD. Exposure to Radiation from the Natural Radioactivity in Building Materials. In Reported by a Group of Experts of the OECD; Nuclear Energy Agency: Paris, France, 1979.

59. Dragovic, S.; Jankovic, M.L.; Dragovic, R.; Đorđevic, M.; Dokic, M. Spatial distribution of the ${ }^{226}$ Ra activity concentrations in well and spring waters in Serbia and their relation to geological formations. J. Geochem. 2012, 112, 206-211. [CrossRef]

60. Khandaker, M.U.; Uwatse, O.B.; Shamsul Khairi, K.A.; Faruque, M.R.I.; Bradley, D.A. Terrestrial radionuclides in surface (dam) water and concomitant dose inmetropolitan Kuala Lumpur. Radiat. Prot. Dosim. 2019, 185, 1-8.

61. Titus, A.; Pereira, G.N. Potassium Dynamics in Coffee Soils. 2016. Available online: https:/ / ecofriendlycoffee.org/potassiumdynamics-coffeesoils / (accessed on 12 February 2021).

62. Duc, H.H.; Minh, N.D.; Cuong, P.V.; Anh, L.T.; Leuangtakoun, S.; Loat, B.V. Transfer of ${ }^{238} \mathrm{U}$ and ${ }^{232}$ Th from Soils to Tea Leaves on Luong My Farm, Hoa Binh Province, Vietnam, VNU. J. Sci. Math. Phys. 2019, 35, 106-115. 
63. International Atomic Energy Agency (IAEA). Handbook ofparameter values for the prediction of radionuclide transfer in terrestrialand freshwater environments. In Technical Report series No. 472; IAEA: Vienna, Austria, 2010.

64. Frissel, M.J. Generic values for soil-to-plant transfer factors of radiocesium. J. Environ. Radioact. 2002, 58, 113-128. [CrossRef]

65. Sabbarese, C.; Ambrosino, F.; D'Onofrio, A.; Roca, V. Radiological characterization of natural building materials from the Campania region (Southern Italy). Constr. Build. Mater. 2021, 268, 121087. [CrossRef]

66. Jannatul, F.; Munmun, N.N.; Rahman, R.R. Assessment of Radionuclide Concentrations in Tea Samples Cultivated in Chittagong Region, Bangladesh. Int. J. Life Sci. Technol. 2018, 11, 20-30.

67. Recep, K.; Filiz, K.G.; Nilay, A.; Nazmi, T.O. Radionuclide concentration in tea, cabbage, orange, kiwi and soil and lifetime cancer risk due to gamma radioactivity in Rize. Turk. Soc. Chem. Ind. 2011, 91, 987-991.

68. Önder, K.; Murat, B.; Sayhan, T.; Yavuz, Ç. ${ }^{232} \mathrm{Th},{ }^{238} \mathrm{U},{ }^{40} \mathrm{~K},{ }^{137} \mathrm{Cs}$ radioactivity concentrations and ${ }^{137} \mathrm{Cs}$ dose rate in Turkish market tea. Radiat. Eff. Defects Solids 2009, 164, 138-143.

69. Milutin, J.; Natasa, L.; Snezana, P.; Milan, O. Radionuclide concentrations in samples of medicinal herbs and effective dose from ingestion of $137 \mathrm{Cs}$ and natural radionuclides in herbal tea products from Serbian market. Isot. Environ. Health Stud. 2011, 47, 87-92.

70. Khandaker, M.U.; Nasir, N.L.M.; Zakirin, N.S.; Kassim, H.A.; Asaduzzaman, K.; Bradley, D.A.; Zulkifly, M.Y.; Hayyan, A. Radiation dose to the Malaysian populace via the consumption of bottled mineral water. Radiat. Phys. Chem. 2017, 140, 173-179. [CrossRef]

71. Khandaker, M.U.; Wahib, N.B.; Amin, Y.M.; Bradley, D.A. Committed effective dose from naturally occurring radionuclides in shellfish. Radiat. Phys. Chem. 2013, 88, 1-8. [CrossRef]

72. Health Effects of Radium Radiation Exposure. Available online: https://www.mass.gov/service-details/health-effects-ofradium-radiation-exposure\# (accessed on 13 February 2020). 